\title{
Q. DIALEKTIKA
}

ISSN: 2338-2635

\section{GRAMMATICAL ERROR ANALYSIS ON THE THESIS ABSTRACT OF THE MASTER MANAGEMENT PROGRAM'S STUDENTS, FACULTY OF ECONOMICS, DIPONEGORO UNIVERSITY}

\author{
Yules Orlando Sianipar \\ Fakultas Sastra, Universitas Kristen Indonesia \\ Yules.sianipar@uki.ac.id
}

\begin{abstract}
Abstrak
Dalam menulis bahasa Inggris, pembelajar Bahasa kedua sering membuat kesalahan dikarenakan kurangnya menguasai bahasa Inggris diakibatkan sedikitnya pengetahuan mengenai bahasa Inggris, Tujuan penelitian ini adalah untuk melihat variasi kesalahan tata Bahasa yang dilakukanoleh pembelajar Bahasa kedua. Dalam penelitian ini, data utama yang digunakan adalah sampel dari 50 abstrak tesis mahasiswa program magister, fakultas ekonomi dari Universitas Diponegoro., yang diambil penulis secara acak. Data tersebut dianalisa menggunakan Sruface Structure Taxonomy, diantaranya omission, addition, misformation dan misordering, dan menggunakan pendapat dari Brook yang mengatakan ada 4 alasan umum kesalahan tersebut dilakukan oleh pembelajar Bahasa kedua. Hasil penelitian ini menunjukan bahwa kesalahan terbesar yang terjadi adalah misformation, terutama misformation dari to be, kesalahan berikutnya secara berurutan adalah omission, addition dan misordering. Sebagai tambahan, kesalahan yang terjadi kebanyakan karena pengaruh Bahasa pertama dan mengeneralisasikan kata-kata; kedua hal inilah yang disebutkan oleh Brook.
\end{abstract}

\section{Kata Kunci: Pembelajar Bahasa kedua, Kesalahan tata Bahasa,}

\begin{abstract}
In writing English, second language learners often make errors due to the lack of mastering English or insufficient knowledge about English. The purpose of the research is to look at varieties of second language learners' grammatical errors. In this research, the primary data used are samples from 50 theses abstracts that come from the students of Economics Faculty, magisterial management program of Diponegoro University, which the writer took randomly. The data is analyzed using the surface structure taxonomy, namely omission, addition, misformation, and misordering. They are using Brook's opinion, saying that there are four common reasons for the error made by second language learners. The research shows that the most significant number of mistakes is concerned with misformation. The other errors belong to omission, addition, and misordering, respectively. Besides, their errors are caused mainly by first language interference and overgeneralization; Brook mentions these two reasons. (Ellis, 1993: 159.)
\end{abstract}

\section{Keywords: Second language learner, Grammatical error, Surface Structure Taxonomy}

\section{Background of the problem}

Communication is something we always do with others. When we communicate, we use language as a medium of communication. Communication can happen not only in oral 
form but also in written form. That is why the connection between writing and the way we communicate has a tight bond. Elder (1990: 9) says, "writing is more than just a skill required of students. People who can write, they write. Writing, by its very nature, becomes a vehicle that carries them towards clearer and sophisticated thinking. Furthermore, writing skills are communication skills. A person who practices the organizations and presents ideas and opinions in writing learn to speak more effectively becomes a better communication."

English has become an essential language in Indonesia after the national language, the Indonesian language. In addition, English has become a worldwide language, meaning that we can use the English language as our language everywhere we go.

That is why the government in Ketetapan Menteri Pendidikan \& Kebudayaan RI no 097/1967, tanggal 12 desember 1967 tentang fungsi dan tujuan pengajaran pada lembaga pendidikan tingkatan lanjutan dalam pendidikan dan kebudayaan (Alwasilah, 1985) decided English as a subject in every stage of education. It means that English has become a subject for every school stage, from elementary to high school. Consequently, nowadays, children can learn English from the lowest level of education. Moreover, even some schools use English as their medium language in teaching and communicating among teachers and students. This phenomenon makes language courses grow faster and spread out in Indonesia, such as LIA, EF, and ILP.

Although the English language has grown faster and the medium to learn English has spread worldwide, there are errors in writing English; even they appear a lot in educational sectors, like schools and universities. The students still make mistakes in writing their assignments or tests; even some students cannot speak English fluently.

However, Corder (1975:11) said that making mistakes is natural in first language learning and second language learning. Errors that happen when using a specific language are standard for every person who learn a foreign language. The mistakes usually happen in the oral and written learning process from the learners. Maybe this phenomenon happens because of a lack of attention in learning it or some difficulties they face in learning it. Although some made a mistake, some are good or even make a good grade in writing English and also can speak English fluently,

To prove whether those mistakes occur in university students, the writer examines the thesis's abstract writing from the faculty of economics' master program of management students of Universitas Diponegoro or UNDIP. What kinds of errors exist in those abstract writing? 
According to Norrish (1983: 21), "there are common mistakes that made by the second language learners, they are:

a. Carelessness

It is reckless, a kind of mistake that bonds tightly with the lack of motivation of the student/learner to study.

b. First language interference

There has been an influence from the first language that caused the student to learn the second language.

c. Translation

In this part, Norrish emphasizes that there should be a clear border between interference and translation.

Interference is an influence that comes without the student's consciousness. For example, it happens when the person is studying a second language."

Norrish (1983: 7-8) also said, "errors in language classified into:

a. Error; it happens when foreign language learners have not consistently studied the rule yet, so it causes violation in a language rule.

b. Mistake; it happens when the learners are not consistent in choosing the word or expression for a certain situation.

c. Lapse; happens unintentionally, and it is related to concentration, memory, capacity, fatigue, and stress. It can happen both in native speakers and in second language learners.

d. Careless slip; happens because the learners pay less attention to the material given in the learning process."

Surface Structure Taxonomy is a classification system based on the ways surface structures are altered. Learners may omit required elements or add unnecessary ones. They may misform items or misorder them." (Dulay, Burt, and Krashen, 1982: 150)

According to Dulay, Burt, and Krashen in James (1998: 106-112), "Surface Structure Taxonomy divided into four parts, such as:

a. Omission

The errors belonging to this category are marked by the absence of an essential item that should be appeared in grammatical sentences.

Ex: John manager new company 
Language learners omit grammatical morphemes much more frequently than content words.

The correct sentence should be:

John is the manager of the new company.

b. Addition

They are characterized by the presence of an item that must not appear in a wellformed utterance.

Ex: Martha does like me.

c. Misformation

It is characterized by the use of the wrong form of the morpheme or structure. Misordering

It is characterized by the incorrect placement of a morpheme or group of morphemes as an utterance.

Example: He is going on Monday to Jakarta.

The correct sentence should be: He is going to Jakarta on Monday.

\section{Research Methodology and Data Collection}

"What makes the research happens was an existence of a will to know about things that unknown before, understand the cause and effect of the problem that we face, and the desire to find new things and test the efficiency of the natural procedure that already exists." (Semi, 1993: 9). Suryabrata (1983) says "before doing a research, we need to make the outline that we going to use and also the alternatives." In doing an observation, we have to decide what kind of observations we will use. After that, we make the composition of the observation and the alternatives that might we used to gain the purpose of our observations.

In this observation, the writer used descriptive research because the writer was trying to image mistakes that we usually did not realize, especially in writing thesis' abstract, which usually most of us give little attention, especially the composition of words and tenses used. The method of data gathering the writer used is the documentation method. According to Arikanto (1993: 202), "Documentation method is a method that uses to find data about things or variables in the form of notes, newspapers, magazines, inscription, the result of a meeting (in a shape of writing), agenda." Data that I will use as a documentation method is the students' thesis abstract of the Faculty of Economics, the master program of management, Universitas Diponegoro or UNDIP. 
The population is the sum of the whole source, which will be analyzed with the characteristic that will be generalized. (Hadi, 2001: 2) "Population is a group of individuals with determining quality and characteristic. In other words, the population is the entire group from which the sample is chosen." The population is formed in an abstract thread in the student's paper that takes the master program of management from economics, Universitas Diponegoro (UNDIP). Parts of the population usually call samples. (Hadi, 2001: 2), conveys that sample refers to the strategy that enables us to pick a sub-group from the large group and then use the subgroup as the basis for making a judgment about the large group, for Arikunto $(1996,117)$ said that sample is a part of the population which is supposed to represent the characteristics of the population. Kontjoroningrat (1994: 89), "Metode pemilihan sampel / sampling dibagi menjadi 2 :

a) Metode simple random sampling: metode pengambilan sampel secara acak atau dengan tidak pandang bulu dimana setiap individu dalam populasi memiliki kesempatan untuk terpilih menjadi sampel.

b) Metode purposive non random: metode penelitian sampel berdasarkan tujuan yang hendak dicapai dalam suatu penelitian. Sampel disini sengaja dipilih untuk tujuan tertentu atau mendeskripsikan gejala-gejala yang ada.

The writer's method for sample taking is the random sampling method because of the large sum of the thesis population, more than 200 theses. Therefore, the sample is 50 theses, which were taken randomly from each of the bookshelves.

The steps the writer used in collecting the data are:

a) Search the students' thesis from the faculty of economics that takes the magisterial management program, Christian University of Indonesia.

b) Write the abstracts that, for me as a writer, contains mistakes is the writing after that, the data are:

c) Mark the mistakes with a pen.

d) Re-write back the mistakes that I found on a blank paper, then analyzed them.

\section{Data analysis}

\section{Surface Structure Taxonomy}

According to surface structure taxonomy, errors that happen in learning a second language such as:

1. Omission 
The omission will divide into several types; they are:

a. Omission of to be

1) (Framing, Tanggung Jawab dan Pengalaman dalam Pembuatan Keputusan Pembuatan Kredit.(1) Page v, parag 5, first sentence)

"The results show that there no difference in the experienced individual decisions and inexperienced ones," $\rightarrow$ "The results show that there $\underline{\text { s }}$ no difference in the experienced individual decisions and experienced ones,"

2) (Analisis Faktor-Faktor yang Mempengaruhi Intensitas Distribusi Obat yang Berdampak pada Kinerja Pemasaran.(5) Page iv, paragraph 1, third sentence) "First, the manufacturer's brand strategy includes the product quality and the target focus." $\rightarrow$ "First, the manufacturer's brand, which includes the product quality and the target focus."

In no 1 , because the subject is singular, the result, so the 'to be will be, is.

However, there is a sentence in the word after 'to be' changes because the sentence is 'present progressive tense."

The form: Subject + to be + infinitive $+\mathrm{v}$-ing

In sentence no 2, the subject is manufacturer brand's because the subject is "singular' so the appropriate 'to be' is; is. Because the activity still happens when the sentence is made so we can call it 'present progressive sentence', and the word that combines with the 'v-ing' includes and becomes including.

b. Omission of preposition

(Implementasi Metode Kualitas Six Sigma dalam Analisis Pengendalian Kualitas (34) Page v, fourth paragraph, fourth sentence)

"The goal MEASURE phase of Six Sigma strategy is to gather information about the current situation...." $\rightarrow$ "The goal of MEASURE phase of Six Sigma strategy is to gather information about the current situation..."

Before, it combines with 'preposition.' The word the goal did not give a clear meaning to which word the goal referred to. When the goal combines with 'preposition' of, it is clear to which word it refers to Measure of phase Six Sigma.

c. Omission of article

1) (Mempengaruhi Kredit Macet pada PT. BPR Karticentra Artha Mranggen Kabupaten Demak.(2) Page iv. First paragraph, last sentence) 


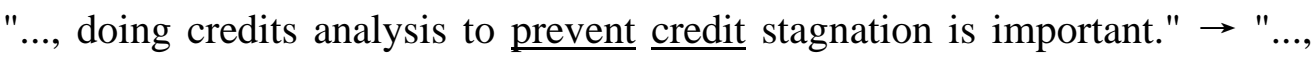
doing a credits (addition) analysis to prevent a credit stagnation is important." (..., doing a credit analysis to prevent a credit stagnation is important."

2) (Peranan Komunikasi Pemasaran dan Hubungan Kemitraan dalam Meningkatkan Kinerja Pemasaran dan Membangun Keunggulan Bersaing Berkelanjutan.(12) Page ix. Third paragraph, first sentence)

"..that there was a significant effect among proposed variables of this study in which value of goodness-of-fit criteria indicated..." $\rightarrow$ "... that there was $\underline{a}$ significant effect among proposed variables of this study in which value of goodness-of-fit criteria indicated..."

In number 1, the subject should become 'singular' because the 'to be' used is, so the word credits should become credit and combine with the 'article' $\mathbf{a}$.

In number 2, the sentence's subject is 'singular', so it should be combined with 'article' a.

2. Addition

Addition errors usually occur when the learners have already acquired some target language rules.

a. Addition of verb

1) (Analisis Faktor Kepuasan Pelayanan Nasabah Kredit Umum Pedesaan Golongan Berpenghasilan Tetap BRI Unit.(25) Page v. Last paragraph, sixth sentence)

"The factors would have special suggest from the management to be formulated into their service quality." $\rightarrow$ "The factors would have special suggest from the management to be formulated into their service quality."

In this part, the writer put unnecessary verbs in the sentence, making the sentence's meaning unclear.

b. Addition of to be

1) Analisis Faktor-Faktor yang Mempengaruhi Keunggulan Produk Baru dalam Rangka Meningkatkan Kinerja Ekspor.(36) Page iv. First paragraph, first sentence)

"The primary objectives of this research is to analyze are factors that influence export performance." $\rightarrow$ "The primary objective of this research is to analyze factors that influence export performance." 
The word Primary is singular, so the right 'to be' should be is not are, and also the word objectives transformed into objective due to the word Primary.

c. Addition of preposition

1) (Analisis Faktor-Faktor yang Mempengaruhi Keunggulan Produk Baru dalam Rangka Meningkatkan Kinerja Ekspor.(36) Page iv. First paragraph, first sentence)

"The primary objectives of this research is to analyze are factors that influence export performance." $\rightarrow$ "The primary objective of this research is to analyze factors that influence export performance."

2) (Efisiensi dan Peningkatan Kerja Tempat Pelelangan Ikan (TPI).(29) Page vii. Second paragraph, first sentence)

"Analytical technique was used of Data of Envelopment Analysis (DEA) to measure the efficiency of the TPI observed." $\rightarrow$ "Analytical technique was(misformation) used Data of Envelopment Analysis (DEA) to measure the efficiency of the TPI observed." ("Analytical technique to be used Data of Envelopment Analysis (DEA) to measure the efficiency of the TPI observed." In number 1, there are two 'to be,' is, and are, so eliminating the 'to be' are will give a clear meaning for the sentence. Moreover, the 'preposition to is not proper to place in the sentence because it will give ambiguous meaning.

In number 2, the sentence still adds a 'preposition' that is not appropriate with the sentence. 'The preposition' is useless, as the sentence needs the verb 'use' and should be followed by an object directly without any preposition.

3. Misformation

It is characterized by the use of the wrong form of the morpheme or structure.

a. Misformation of to be

1) (Framing. Tanggung Jawab dan Pengalaman dalam Pembuatan Keputusan Pemberian Kredit.(1) Page v. Second paragraph, last sentence)

"Data is analyzed using one-way analysis of variance (ANOVA) test,...) $\rightarrow$ "Data are analyzed using one-way analysis of variance (ANOVA) test,...)

2) (Analisis Persepsi Terhadap Faktor-Fasktor Yang Mempengaruhi Kredit Macet Pada PT. BPR Kartikacentra Artha Mranggen, kabupaten Demak.(2)Page iv. First paragraph, second sentence) 
"Credits (addition) are a highly risky business because there are chances that it(addition) cannot be collected..." $\rightarrow$ "Credit is a high-risk business because there are chances that cannot be collected..."

In number 1, 'to be' is for present tense, while the sentence is past tense, so the proper 'to be' is was.

In number 2, the subject is singular' because of the presence of an article, a. It means that 'to be' should be singular (is), not plural (are).

4. Misordering

It is characterized by the incorrect placement of a morpheme or group of morphemes in an utterance.

a) (Analisis Pengaruh Integrasi Strategik Dan Orientasi Pasar Terhadap Keunggulan Bersaing Berkelanjutan (studi kasus pada industry mebel besar dan sedang di Jawa Tengah),(38) page iv, second paragraph, third sentence)

"Data that gathered from no respondents consists of firm big and middle at furniture in Semarang..." $\rightarrow$ "Data that gathered from no respondents consists of big firm and middle at furniture in Semarang..."

b) (Analisis Pengaruh Agilitas Pemasok Dan Faktor-Faktor Kualitas Hubungan Terhadap Kinerja Rantai Pasokan (studi kasus pada perusahaan rekanan PT. Indonesia Power UBP Semarang),(40) page v, second paragraph, first sentence) "Some research at the past, more discuss agility and relationship quality in separate...." $\rightarrow$ "Some research at the past, discuss more agility and relationship quality in separate...."

In this section, the original sentences have to be re-ordered because they do not give a clear meaning

\section{How the Error Happens}

According to Brook's opinion (Ellis, 1993: 159.), there are four common reasons for errors made by second language learners, as follows:

1. The learners do not know the structural pattern, so they make a random response

2. The correct model has been insufficiently practical

3. The first language may induce distortion

4. The student may follow the general rule, which is not applicable in a particular instance 
As mentioned before, the writer did not discuss numbers 1 and 2 since they related to the writers' abilities and conditions. Therefore, the writer analyzed the students' errors of a magisterial program of management of Diponegoro University by referring to numbers 3 $\& 4$.

1. The first language may induce distortion

a. The use of to be

Example:

1) The result show that there no difference in the experienced individual decisions and inexperienced ones,.. (Framing, tanggung jawab dan Pengalaman Dalam Pembuatan keputusan Kredit.(1) Page v, last paragraph, first sentence)

2) .... it found that this research model is well correlated and proveable. (Analisis Faktor-Faktor Yang Mempengaruhi Persepsi Divisi Marketing Tentang Inovasi Produk Terhadap Peningkatan Kinerja Pemasaran (studi kasus pada pemasaran telekomunikasi selular GSM di Jawa Tengah \& DIY),(33) page iii, paragraph four, first sentence)

The following are the meaning of the above sentences in Indonesia:

1) Hasilnya menunjukkan bahwa tidak ada perbedaan antara yang berpengalaman dengan yang tidak berpengalaman dalam mengambil keputusan.

2) .., ditemukan bahwa model penelititan sangat berhubungan dan terbukti

In the Indonesian language the word 'adalah' can be omitted because with or without it we can still call it a right sentence. But, in English without 'to be', the sentence will not give a clear meaning. The correct ones should be:

1) The result show that there is no difference in the experienced individual decisions and inexperienced ones.

2) .., it is found that this research model is well correlated and provable.

b. The use of a preposition

\section{Example:}

1) The goal measure phase of the SIX SIGMA strategy is to gather information about the correct situation,.. (Implementasi Metode Kualitas Six Sigma Dalam Analisa Pengendalian Kualitas (studi kasus pada bengkel mesin plastic Varia Kebumen),(34) page v, paragraph four, fourth sentence) 
2) The achieving result from this research that all independent variables are significantly affecting the profit growth for one year forward at the significant level of 5\%. (Arief Himmawan,(45) page v, last paragraph, first sentence)

In Indonesia, the use of the preposition 'of' is not necessary. Thus, the correct one should be:

1) The goal of the measure phase of the SIX SIGMA strategy is to gather information about the correct situation.

2) The achieving result from this research that all independent variables are significantly affecting the profit growth for one year forward at the significant level of $5 \%$.

c. The use of word order

\section{Example:}

1) Data that gathered from no respondents consists of firm big and middle at furniture in Semarang... (Analisis Pengaruh Integrasi Strategik Dan Orientasi Pasar Terhadap Keunggulan Bersaing Berkelanjutan (studi kasus pada industry mebel besar dan sedang di Jawa Tengah).(38) page iv, second paragraph, third sentence)

2) Some research at the past, more discuss agility and relationship quality in separate... (Analisis Pengaruh Agilitas Pemasok Dan Faktor-Faktor Kualitas Hubungan Terhadap Kinerja Rantai Pasokan (studi kasus pada perusahaan rekanan PT. Indonesia Power UBP Semarang,(40) page v, second paragraph, first sentence)

In this part, the word that bolded is not in the proper place. Therefore, if the bolded word we translate into Indonesia language will be:

Firm big = besar perusahaan

More discuss $=$ dibahas lebih

So, it should be:

1) Data that gathered from no respondents consists of big firm and middle at furniture in Semarang...

2) Some research in the past discusses more agility and relationship quality separate...

2. The student may follow the general rule, which is not applicable in a particular instance 
a. The use suffix-s

Example:

1) Data form 100 product/drug brands comprising of analgesics,.. (Analisis FaktorFaktor Yang Mempengaruhi Intensitas Distribusi Obat Yang Berdampak Pada Kinerja Pemasaran,(5) page iv, paragraph three, first sentence)

2) The respondent were asked questionnaire the item addressing to rate 6 attributes... (Analisis Pengaruh Kualitas Jasa Terhadap Peningkatan Loyalitas Nasabah Studi Confirmatory Pada PT. ORIX Finance Cabang Surakarta,(14) page vii, paragraph three, fourth sentence)

The verb word will be modified according to the subjects, tenses, and verb position in the sentences in every sense. They should be:

1) Data form 100 products/drug brands comprising of analgesics,..

2) The respondents were asked to questionnaire the item addressing to rate six attributes,..

b. The use of an adjective

Example:

1) Sell phone industries have become more competitive. (Analisis Pengaruh Konteks Media Dan Kreatifitas Iklan Terhadap Efektifitas Iklan Yang Mempengaruhi Sikap Terhadap Merek (studi kasus pada konsumen merek simcard prabayar di kota Semarang).(17) page v, first paragraph, first sentence)

2) For making this thesis I have done research with BRI Demak branch office customer as a responden. (Analisis Faktor-Faktor Yang Mempengaruhi Kepuasan Pelanggan Dan Pengaruhnya Terhadap Loyalitas Pelanggan (21) page iv, paragraph three, first sentence)

The correct sentences should be:

1) Cell phone industries have become more competitive.

2) For doing this thesis, I have researched with BRI Demak branch office customers as a respondent.

\section{Conclusion}


The conclusion is that the highest errors done by the students of the management magisterial program of the Faculty of Economics, Diponegoro University, according to the surface structure taxonomy, is misformation, the second is the omission, the third is the addition, and the last is misordering. According to the four common reasons errors made by second language learners (Brook's opinion), comparing the examples induced by the first language and following the general rule is almost the same. The paragraph above shows that there is a lack of mastering English, especially in understanding grammar.

\section{Suggestion}

Learning a second language is evident for us to make mistakes or find obstacles to understand it. However, as we know, English has become more critical because we can interact with foreign people by mastering it.

\section{References}

Alwasilah, A. Chaedar. 1985. Sosiologi Bahasa. Bandung: Angkasa Pura.

Arikunto, Suharsimi. 1993. Prosedur Penelitian. Yogyakarta: Rineka Cipta.

Arikunto, Suharsimi. 1996. Prosedur Penelitian-Suatu Pendekatan Praktik. Jakarta: PT. Rineka Cipta.

Borsley, Robert D. 1991. Syntactic Theory: A Unified Approach. London: Arnold.

Dulay, Heidi, et al. 1982. Language Two. Oxford: University Press.

Elder, Dana C. 1990. English Business Letter. Essex: Longman.

Ellis, Rod. 1993. Understanding Second Language Acquisition. Oxford: Oxford University Press.

Fromkin. Victoria. 1988. An Introduction to Language. Cambridge: Cambridge University Press.

Hadi, Sutrisno. 2001. Methodology Research (Jilid 3). Yogyakarta: Penerbit ANDI. Halliday, MAK \& Hasan, Ruqaiya. 1992. Bahasa, Konteks, dan Teks Dalam Perspektif

Semiotik Sosial (Translated Edition). Yogyakarta: Gadja Mada University Press.

James, Carl. 1998. Errors in Language Learning and Use. Longman: London and New york. Klaus \& Scholes. Elements of Writing. New York: Oxford University.

Koentjaraningrat. 1993. Metode-Metode Penelitian Masyarakat. Jakarta: Gramedia 
GRAMMATICAL ERROR ANALYSIS ON THE THESIS ABSTRACT OF THE MASTER MANAGEMENT PROGRAM'S STUDENTS, FACULTY OF ECONOMICS, CHRISTIAN UNIVERSITY OF INDONESIA

Norrish, John. 1983. Language and Their Errors. London: Macmillan Publisher, Ltd.

Nurhadi, Drs., M. Pd. 1995. Landasan Penyusunan Buku Pelajaran Bahasa. Semarang: IKIP Semarang Press.

Oshima, Alice and Hogue. 1999. Writing Academic English Third Edition. New York.

Quirck, R., S. Greenbaum, G.Leech and J. Svartvik. 1985. A Comprehensive Grammar of The English Language. London: Longman.

Ramelan. 1992. Introduction to Linguistic Analysis. Semarang: IKIP Semarang Press.

Semi, Attar. 1993. Metode Penelitian. Bandung: Angkasa.

Suryabrata, Sumadi. 1983. Metodologi Penelitian. Jakarta: CV. Rajawali.

Tarigan, Henry Guntur. 1986. Menulis sebagai Suatu Ketrampilan Berbahasa. Bandung: Angkasa.

Venhaar, J. W. M. 1993. Asas-Asas Linguistik Umum. Yogyakarta: Gadjah Mada University Press. 